\title{
PENGARUH INOKULUM CAMPURAN Lactobacillus plantarum DAN Saccharomyces cerevisiae TERHADAP KUALITAS ORGANOLEPTIK, FISIK, DAN KIMIA SILASE KULIT BUAH KAKAO
}

\section{THE EFFECTS OF Lactobacillus plantarum AND Saccharomyces cerevisiae INOCULANT MIXTURE CULTURE ON ORGANOLEPTICAL, PHYSICAL AND CHEMICAL QUALITY OF COCOA POD SILAGE}

\author{
Muhammad Askari Zakariah*, Ristianto Utomo, dan Zaenal Bachruddin \\ Fakultas Peternakan, Universitas Gadjah Mada, Yogyakarta, 55281
}

Submitted: 19 August 2014, Accepted: 2 January 2015

\begin{abstract}
INTISARI
Penelitian bertujuan untuk mengetahui pengaruh inokulan campuran Lactobacillus plantarum dan Saccharomyces cerevisiae pada silase kulit buah kakao (KBK) terhadap kualitas organoleptik, fisik, dan kimia. Penelitian terdiri dari empat perlakuan yaitu silase KBK tanpa penambahan inokulan sebagai kontrol $(\mathrm{K})$, silase $\mathrm{KBK}$ dengan penambahan $L$. plantarum $(\mathrm{KLp})$, silase KBK dengan penambahan S. cerevisiae (KSc), silase KBK dengan penambahan campuran L. plantarum dan S. cerevisiae (KLp+Sc), masingmasing perlakuan ditambah tepung gaplek sebagai bahan tambahan. Perlakuan dilakukan dalam tiga replikasi kemudian diperam selama 21 hari. Variabel yang diamati meliputi kualitas organoleptik (warna, aroma, tekstur, dan keberadaan jamur), kualitas fisik (derajat keasaman), dan kualitas kimia meliputi kadar asam laktat dan komposisi kimia (analisis proksimat). Data kualitas organoleptik dianalisis non-parametrik yaitu uji Hedonik Kruskal-Wallis dengan panelis sebanyak 12 orang, sedangkan fisik dan kimia yang diperoleh dianalisis dengan Analysis of Variance pola searah, apabila terdapat perbedaan yang nyata dilanjutkan dengan uji Duncan New Multiple Range Test. Hasil penelitian menunjukkan bahwa penggunaan L. plantarum dan $S$. cereviciae secara tunggal dan campuran berpengaruh nyata $(P<0,05)$ pada kualitas organoleptik (warna dan keberadaan jamur) dan kimia (bahan kering, bahan organik, ekstrak eter, dan bahan ekstrak tanpa nitrogen). Inokulasi campuran L. plantarum dan S. cerevisiae memiliki kandungan bahan kering dan bahan organik yang tinggi (masing-masing $22,66 \%$ vs $20,38 \%$ dan $94,43 \%$ vs $93,72 \%$ ), bahan ekstrak tanpa nitrogen yang tinggi (masing-masing 75,46\% vs 70,51\%), dan ekstrak eter yang rendah (masing-masing $0,15 \%$ vs $0,87 \%$ ), dibanding kontrol. Disimpulkan bahwa penggunaan campuran $L$. plantarum dan S. cerevisiae pada silase KBK dapat meningkatkan kualitas organoleptik dan kimia.
\end{abstract}

(Kata kunci: Kulit buah kakao, Lactobacillus plantarum, Saccharomyces cerevisiae, Silase)

\section{ABSTRACT}

This research was done to determine the effect of L. plantarum and S. cerevisiae innoculated into cocoa pod silage on organoleptic, physical and chemical quality. This experiment consist of four treatments namely silage of fresh harvested cocoa pods without inoculant as control (K); inoculated with L. plantarum $(K L p) ;$ innoculated with S. cerevisiae (KSc); and innoculated with both L. plantarum and S. cerevisiae mixture $(K L p+S c)$ was cassava meal added as supplement. Each treatment was replicated 3 time. Ensilage was done for 21 days. Variables observed were properties of organoleptic (i.e. color, odor, texture and existence of fungal), physical ( $\mathrm{pH}$ ), and chemical (i.e. lactic acid content, content of dry matter (DM), organic matter (OM), crude protein (CP), ether extract (EE), crude fiber (CF) and nitrogen free extract (NFE)). Collected data of organoleptic characteristic were analyzed by non-parametric test (Hedonic KruskalWallis), whereas physical and chemical data analyzed by one-way analysis of variance and followed by Duncan's New Multiple Range Test for significant difference. Result showed the inoculum have effect $(P<0.05)$ on characteristic of organoleptic (color and avaibility fungus) and chemical (dry matter, organic matter, extract ether, and nitrogen free extract content). Silage with inoculation $L p+S c$ on silage significantly $(P<0.05)$ had higher DM and OM concentration $(22.66 \%$ vs $20.38 \%$ and $94.43 \%$ vs $93.72 \%)$, higher NFE ( $75.46 \%$ vs $70.51 \%)$ and lower EE $(0.15 \%$ vs $0.87 \%$, respectively), compared to control. Based on result, it can be concluded that silage with L. plantarum and S. cerevisiae mixture have better quality.

(Key words: Cocoa pod, Lactobacillus plantarum, Saccharomyces cerevisiae, Silage)

\footnotetext{
*Korespondensi (corsesponding author):

Telp. +62 85729816427

E-mail: m.askari.zakariah@mail.ugm.ac.id
} 


\section{Pendahuluan}

Kulit buah kakao (KBK) mengandung kadar air (KA) yang cukup tinggi, yang menyebabkan KBK dalam jangka waktu tiga hari membusuk sehingga tidak dapat digunakan sebagai pakan ternak ruminansia. Oleh karena itu perlu dilakukan upaya pengawetan KBK, sehingga dapat digunakan dalam jangka waktu panjang dan tidak menurunkan kualitasnya. Salah satu pengawetan yang dapat dilakukan adalah pembuatan silase. Bahan aditif silase berupa inokulan biasa digunakan dalam mendukung proses silase. Lactobacillus plantarum merupakan salah satu inokulan yang berfungsi untuk memproduksi asam laktat untuk menghambat pertumbuhan mikrobia pembusuk dan patogen di dalam silase.

Penambahan L. plantarum pada silase menyebabkan penurunan $\mathrm{pH}$ yang cukup cepat serta menghambat mikroorganisme pembusuk (Adesoji et al., 2010). Inokulan L. plantarum memiliki potensi untuk meningkatkan produktivitas silase dengan meningkatkan kandungan asam laktat, mengurangi kehilangan bahan kering, dan menurunkan pH (Aquilina et al., 2012). Penggunaan bakteri asam laktat pada proses silase berfungi untuk mempercepat laju fermentasi, menghasilkan asam laktat yang tinggi, menurunkan $\mathrm{pH}$, mengurangi proteolisis serta dapat meningkatkan kinerja ternak (Barnes et al., 2007).

Penambahan sumber karbohidrat terlarut seperti tepung gaplek berfungsi sebagai sumber glukosa yang akan diubah menjadi asam laktat. Penambahan sumber karbohidrat terlarut pada silase bertujuan untuk meningkatkan bahan kering dan menstimulasi bakteri asam laktat (Li dan Nishino, 2011). Penambahan $20 \%$ (w/w) dari berat segar, menghasilkan silase yang berkualitas lebih baik dibandingkan jagung dan pollard (Despal et al., 2011).

Penggunaan inokulan $S$. cerevisiae berfungsi sebagai agen pengguna oksigen dapat memperpendek fase aerob. Inokulan $S$. cerevisiae mempunyai kemampuan untuk menghasilkan energi dari senyawa organik dalam kondisi aerob (Hippen et al., 2010). Penambahan inokulan $S$. cerevisiae dapat mendukung pertumbuhan bakteri asam laktat (Hippen et al., 2010). Inokulasi campuran L. plantarum dan S. cerevisiae berpotensi untuk meningkatkan kualitas silase. Inokulan $L$. plantarum memiliki kemampuan untuk tumbuh bersama $S$. cerevisiae, penggunaan kombinasi kedua inokulan dapat meningkatkan kualitas fermentasi dan mencegah kerusakan yang disebabkan oleh Clostridia (Sofyan et al., 2011).

Penelitian ini bertujuan untuk mengetahui pengaruh inokulan $L$. plantarum, $S$. cerevisiae dan campurannya pada silase KBK terhadap kualitas organoleptik (warna, aroma, tekstur, dan keberadaan jamur), kualitas fisik $(\mathrm{pH})$, dan kualitas kimia (asam laktat, bahan kering, bahan organik, serat kasar, protein kasar, serat kasar, ekstrak eter, dan bahan ekstrak tanpa nitrogen).

\section{Materi dan Metode}

\section{Persiapan}

Kulit buah kakao segar diperoleh dari perkebunan rakyat kabupaten Gunungkidul. Komposisi kimia kulit buah kakao, gaplek, dan campuran KBK + gaplek sebelum disilase ditampilkan pada Tabel 1. Inokulan $L$. plantarum diperoleh dari Fakultas Peternakan, Universitas Gadjah Mada, yang telah diperam selama 24 jam pada media man rogosa and sharpes (MRS) brooth. Inokulan S. cerevisiae diperoleh dari Pusat Antar Universitas, UGM, yang telah diperam selama 52 jam pada media malt extract (ME) brooth.

\section{Rancangan penelitian}

Penelitian ini terdiri dari empat perlakuan yaitu $\mathrm{KBK}+$ tepung gaplek + aquades sebagai kontrol $(\mathrm{KO}), \mathrm{KO}+\mathrm{L}$. plantarum (KLp), $\mathrm{K} 0+\mathrm{S}$. cerevisiae $(\mathrm{KSc}), \mathrm{K} 0$ + L. plantarum + S. cerevisiae (KLp+Sc). Pembuatan silase (proses fermentasi) skala laboratorium dilakukan pada ruang steril. Ruang fermentasi disemprot disinfektan dan peralatan disterilkan dengan alkohol 90\%. Kulit buah kakao difermentasi dalam kantong plastik warna putih kapasitas $2 \mathrm{~kg}$. Satu $\mathrm{kg}$ KBK (45\%BK) dan $200 \mathrm{~g}$ tepung gaplek (55\%BK) digunakan untuk setiap kantong plastik, dicampur secara merata dengan inokulan L. plantarum, S. cerevisiae dan campurannya (1:1) sebanyak $0,1 \%$ BK. Fermentasi anaerob dilakukan selama 21 hari.

\section{Analisis kualitas organoleptik dan fisik}

Silase KBK setelah dipanen, diletakkan di atas meja untuk dilakukan uji organoleptik meliputi warna, aroma, tekstur, 
dan keberadaan jamur. Skor penilaian uji organoleptik ditampilkan pada Tabel 2 dengan jumlah panelis sebanyak 12 orang. Pengujian fisik berupa $\mathrm{pH}$ asam laktat menggunakan metode (Nahm, 1992), sampel silase KBK ditimbang sebanyak $1 \mathrm{~g}$ kemudian dihaluskan menggunakan mortar dengan ditambahkan aquades sebanyak $5 \mathrm{ml}$, kemudian disaring untuk mendapatkan supernatannya, lalu supernatan tersebut diuji $\mathrm{pH}$ menggunakan $\mathrm{pH}$ meter.

\section{Analisis kualitas kimia}

Pengujian kualitas kimia meliputi kadar asam laktat berdasarkan metode (Baker dan Summerson, 1941), bahan kering (BK), bahan organik (BO), protein kasar (PK), serat kasar (SK) menggunakan metode AOAC (2005), serta ekstrak eter (EE) menurut Kamal (1997).

\section{Analisis data}

Data yang diperoleh dari pengujian organoleptik dianalisis dengan nonparametrik Uji Hedonik Kruskal-Wallis dilanjutkan Duncan's New Multiple Range Test. Pengujian kualitas fisik dan kimia dianalisis dengan analisis varian pola searah, jika terjadi perbedaan karena perlakuan maka dilanjutkan uji Duncan's New Multiple Range Test (Astuti, 1980). Perhitungan dilakukan menggunakan bantuan software personal komputer Statistical Product and Service Solution versi 16.0 (Soleh, 2005).

\section{Hasil dan Pembahasan}

\section{Kualitas organoleptik dan fisik}

Hasil uji kualitas organoleptik (warna, tekstur, aroma, dan keberadaan jamur) dan fisik $\mathrm{pH}$ silase KBK dengan penambahan dan tanpa inokulan tersaji pada Tabel 3. Warna yang dihasilkan silase dengan penambahan dan tanpa inokulan menunjukkan perbedaan yang nyata $(P<0,05)$.

Silase tanpa penambahan inokulan (KO) memiliki warna lebih gelap dibanding silase dengan penambahan inokulan, karena KBK segar yang akan dijadikan silase memiliki jaringan yang masih hidup sehingga pada fase awal terjadi respirasi aerobik secara aktif yang menghasilkan air, $\mathrm{CO}_{2}$, dan panas.

Tabel 1. Komposisi kimia penyusun silase kulit buah kakao (chemical composition of cocoa pod silage)

\begin{tabular}{|c|c|c|c|}
\hline \multirow[b]{2}{*}{ Parameter } & \multicolumn{3}{|c|}{$\begin{array}{c}\text { Persentase berdasarkan BK (\%) (percentage based on } \\
D M(\%))\end{array}$} \\
\hline & $\begin{array}{c}\text { Kulit buah } \\
\text { kakao (KBK) } \\
(\text { cocoa pod) }\end{array}$ & $\begin{array}{l}\text { Tepung gaplek } \\
\text { (cassava meal) }\end{array}$ & $\begin{array}{c}\text { KBK + gaplek sebelum disilase } \\
\text { (cocoa pod + cassava meal } \\
\text { before ensilage) }\end{array}$ \\
\hline Bahan kering (BK) (dry matter $(D M))$ & 13,48 & 86,70 & 26,02 \\
\hline Bahan organik (BO) (organic matter $(\mathrm{OM})$ ) & 88,90 & 99,01 & 94,03 \\
\hline Protein kasar (PK) (crude protein $(C P))$ & 4,06 & 0,89 & 2,51 \\
\hline Serat kasar (SK) (crude fiber $(C F)$ ) & 31,26 & 1,23 & 13,71 \\
\hline Ekstrak eter (EE) (extract ether $(E E)$ ) & 0,97 & 0,99 & 0,52 \\
\hline $\begin{array}{l}\text { Bahan ekstrak tanpa nitrogen (BETN) } \\
\text { (nitrogen free extract (NFE)) }\end{array}$ & 52,61 & 95,90 & 77,29 \\
\hline Theobromine (ppm) & 161,28 & & \\
\hline
\end{tabular}

Tabel 2. Nilai uji kualitas organoleptik untuk panelis (value of organoleptical test for panelist)

\begin{tabular}{|c|c|c|c|c|}
\hline \multirow{2}{*}{$\begin{array}{l}\text { Nilai } \\
\text { (value) }\end{array}$} & \multicolumn{4}{|c|}{ Silase (silage) } \\
\hline & Warna (color) & Aroma (odor) & Tekstur (texture) & $\begin{array}{c}\text { Keberadaan jamur (availability } \\
\text { of fungus) }\end{array}$ \\
\hline 1 & $\begin{array}{l}\text { Kuning } \\
\text { kecoklatan } \\
\text { (tawny) }\end{array}$ & $\begin{array}{l}\text { Asam segar } \\
\text { (freshly acid) }\end{array}$ & $\begin{array}{l}\text { Tidak menggumpal dan tidak } \\
\text { berlendir (no clot and slimy) }\end{array}$ & Tidak ada (not any) \\
\hline 2 & $\begin{array}{l}\text { Coklat } \\
\text { (brown) }\end{array}$ & Asam (acid) & $\begin{array}{l}\text { Sedikit menggumpal dan sedikit } \\
\text { berlendir (slight clot and slimy) }\end{array}$ & Sedikit (little) \\
\hline 3 & $\begin{array}{l}\text { Coklat } \\
\text { kehitaman } \\
\text { (brown dark) }\end{array}$ & $\begin{array}{l}\text { Kurang asam } \\
\text { (less acid) }\end{array}$ & $\begin{array}{l}\text { Agak menggumpal dan berlendir } \\
\text { (intermediate clot and slimy) }\end{array}$ & $\begin{array}{l}\text { Banyak terdapat pada } \\
\text { permukaan (available at } \\
\text { surface) }\end{array}$ \\
\hline 4 & Hitam (dark) & $\begin{array}{l}\text { Busuk } \\
\text { (spoiled) }\end{array}$ & $\begin{array}{l}\text { Banyak menggumpal dan } \\
\text { berlendir (high clot and slimy) }\end{array}$ & $\begin{array}{l}\text { Banyak terdapat di semua titik } \\
\text { pengamatan (high available) }\end{array}$ \\
\hline
\end{tabular}


Panas yang dihasilkan meningkatkan temperatur di dalam silo, temperatur yang meningkat mempengaruhi perubahan warna gelap pada silase. Karakteristik silase yang berkualitas baik beraroma asam, tidak lengket jika digenggam, warna dekat dengan aslinya (kecoklatan) (Sianipar dan Simanihuruk, 2009).

Aroma/bau dan tekstur yang dihasilkan silase KBK dengan penambahan dan tanpa inokulan menunjukkan perbedaan yang tidak nyata. Aroma asam segar yang dihasilkan dari semua perlakuan dan kontrol merupakan salah satu ciri-ciri silase yang berkualitas baik, sedangkan tekstur yang tidak menggumpal dan tidak berlendir yang dimiliki oleh silase menunjukkan bahwa silase KBK berkualitas baik. Hal ini dipengaruhi oleh proses fermentasi yang menghasilkan asam laktat. Silase yang berkualitas baik memiliki tekstur yang lembut, tidak berlendir dan tidak berjamur (Ridla et al., 2007).

Jumlah karbohidrat terlarut yang cukup pada silase dengan adanya penambahan tepung gaplek pada semua perlakuan dan kontrol menjadikan proses fermentasi pati menjadi asam laktat dapat berjalan, sehingga menjadikan kualitas aroma dan tekstur antar perlakuan berbeda tidak nyata. Akselerator fermentasi tepung gaplek yang ditambahkan dalam silase meningkatkan kualitas organoleptik meliputi bau dan tekstur, lebih baik dibandingkan dedak padi dan molases (Kurnianingtyas et al., 2012).

Lendir yang biasa terdapat pada silase merupakan indikasi adanya mikrobia pembusuk. Lendir tersebut dihasilkan oleh mikrobia dari sistem kapsul, sistem kapsul inilah yang menjadikan mikrobia pembusuk dan patogen menjadi resisten terhadap fagositosis sehingga meningkatkan virulensi- nya terhadap ternak. Lendir dihasilkan dari pembebasan sebagian bahan penyusun kapsul mikrobia, lendir sangat mencolok terjadi pada mikroorganisme apabila medium biakannya mengandung sukrosa. Larutan lendir ini seperti gel yang terdiri dari dekstrin (Cai dan Dong, 2010).

Keberadaan jamur pada silase KBK dengan penambahan dan tanpa inokulan menunjukkan perbedaan yang nyata $(P<0,05)$. Penambahan inokulan $L$. plantarum dan $S$. cerevisiae secara tunggal menghasilkan silase KBK dengan hasil uji organoleptik keberadaan jamur yang rendah, sedangkan silase KBK tanpa penambahan inokulan menimbulkan potensi keberadaan jamur yang terdapat pada permukaan. Inokulasi campuran L. plantarum, L. bulgaricus dan S. cerevisiae secara nyata mencegah terjadinya spoilage dari mould (Dalié et al., 2010).

Hasil pengukuran $\mathrm{pH}$ antar perlakuan menunjukkan perbedaan yang tidak nyata. Fermentasi yang terjadi selama proses silase akan menghasilkan asam laktat, asam laktat yang diproduksi menjadikan $\mathrm{pH}$ silase menjadi asam. Semakin banyak koloni bakteri asam laktat yang dihasilkan pada waktu proses silase, maka silase tersebut akan semakin stabil yang ditandai dengan penurunan $\mathrm{pH}$. Kisaran $\mathrm{pH}$ pada silase KBK dengan penambahan maupun tanpa inokulan termasuk pada kategori kualitas silase sangat baik. Selanjutnya, $\mathrm{pH}$ silase yang baik berkisar 3,8-4,2 dan jika $\mathrm{pH}$ silase lebih dari 4,8 ini berarti kegagalan fermentasi (Ranjit dan Kung, 2000).

Penambahan tepung gaplek sebagai sumber karbohidrat terlarut pada silase dirasa cukup untuk pertumbuhan BAL yang terdapat pada silase untuk menghasilkan asam laktat yang dapat menurunkan $\mathrm{pH}$ silase KBK.

Tabel 3. Kualitas organoleptik dan fisik silase kulit buah kakao ditambah gaplek sebagai kontrol (K0), kontrol +

L. plantarum (KLp), kontrol $+S$. cerevisiae $(\mathrm{KSc})$, kontrol + L. plantarum $+S$. cerevisiae $(\mathrm{KLp}+\mathrm{Sc})$ (organoleptical and physical characteristic cocoa pod silage + cassava meal without inoculant as control (KO), control $+L$. plantarum $(K L p)$, control $+S$. cerevisiae $(K S c)$, control + L. plantarum $+S$. cerevisiae $(K L p+S c))$

\begin{tabular}{|c|c|c|c|c|}
\hline \multirow{2}{*}{ Parameter } & \multicolumn{4}{|c|}{ Silase (silage) } \\
\hline & $\mathrm{KO}$ & KLp & $\mathrm{KSc}$ & $\mathrm{KLp}+\mathrm{Sc}$ \\
\hline Warna (color) & $1,92 \pm 0,649^{a}$ & $1,58 \pm 0,554^{b}$ & $1,58 \pm 0,603^{b}$ & $1,41 \pm 0,500^{b}$ \\
\hline Aroma $(\text { odor })^{\mathrm{ns}}$ & $1,77 \pm 0,865$ & $1,41 \pm 0,554$ & $1,83 \pm 0,736$ & $1,63 \pm 0,761$ \\
\hline Tekstur (texture $)^{\text {ns }}$ & $1,72 \pm 0,659$ & $1,53 \pm 0,559$ & $1,50 \pm 0,507$ & $1,47 \pm 0,506$ \\
\hline Jamur (availability fungus) & $1,17 \pm 0,447^{b}$ & $1,00^{\mathrm{a}}$ & $1,00^{\mathrm{a}}$ & $1,03 \pm 0,167^{a}$ \\
\hline $\mathrm{pH}^{\mathrm{ns}}$ & $4,34 \pm 0,095$ & $4,11 \pm 0,263$ & $4,39 \pm 0,118$ & $4,31 \pm 0,136$ \\
\hline
\end{tabular}


Silase KBK tanpa penambahan bahan aditif memiliki pH 7,7. (Cherney et al., 2004) menyatakan bahwa terdapat korelasi yang positif antar karbohidrat larut air dan $\mathrm{pH}$. Karbohidrat larut air dibutuhkan oleh $L$. plantarum untuk memproduksi asam laktat yang menyebabkan penurunan $\mathrm{pH}$ (Ranjit dan Kung, 2000).

\section{Kualitas kimia}

Hasil uji kualitas kimia silase KBK dengan penambahan dan tanpa inokulan meliputi kadar asam laktat, kandungan bahan kering (BK), bahan organik (BO), serat kasar $(\mathrm{SK})$, protein kasar (PK), ekstrak eter (EE), bahan ekstrak tanpa nitrogen (BETN) tersaji pada Tabel 4.

Kadar asam laktat silase KBK dengan penambahan dan tanpa inokulan menunjukkan perbedaan yang tidak nyata. Penelitian ini menunjukkan bahwa terdapat hubungan $\mathrm{pH}$ dan kadar asam laktat, perbedaan yang tidak nyata pada kadar asam laktat menghasilkan $\mathrm{pH}$ yang tidak nyata antar perlakuan. Hal ini disebabkan kadar asam laktat yang semakin tinggi menghasilkan $\mathrm{pH}$ yang semakin rendah.

Kisaran produksi asam laktat silase KBK 1,04-1,52\% BK masih dalam kisaran normal sesuai yang dilaporkan Kualitas silase dari rumput dan hasil sisa pertanian di daerah tropis memiliki kisaran kadar asam laktat sekitar 1,08-3,75\% BK (Heinritz et al., 2012). Hal yang berbeda dilaporkan (McDonald et al., 2002) menyatakan bahwa kandungan asam laktat silase pada umumnya berkisar 8$12 \%$ BK.

Penggunaan sealer dan vacuum pada saat pemasukan bahan-bahan silase ke dalam silo menjadikan kondisi anaerob dapat tercapai pada waktu yang sama. Kondisi anaerob yang terjadi mendukung pertumbuhan bakteri asam laktat yang terdapat di dalam silo untuk memproduksi asam laktat. Penggunaan vacuum pada pembuatan silase akan memperpendek fase aerobik (Johnson et al., 2005).

Kandungan BK silase KBK dengan penambahan dan tanpa inokulan menunjukkan perbedaan yang nyata $(P<0,05)$. Inokulasi L. plantarum (KLp) memiliki kandungan BK yang lebih tinggi dibandingkan dengan silase KBK tanpa penambahan inokulan (K0). Inokulan $L$. plantarum menghasilkan asam laktat dapat mencegah pertumbuhan bakteri pathogen, sehingga menghasilkan silase yang memiliki kandungan BK yang lebih tinggi dibandingkan tanpa inokulasi. Silase KBK dengan inokulasi $S$. cerevisiae memiliki kandungan $\mathrm{BK}$ berbeda tidak nyata terhadap silase tanpa inokulasi (K0), tetapi setelah diinokulasi campuran (kombinasi) dengan $L$. plantarum $(\mathrm{KLp}+\mathrm{Sc})$ dapat menghasilkan silase KBK yang memiliki kandungan BK tertinggi dibandingkan perlakuan yang lain. Jatkauskas dan Vrotniakiene (2007) menyatakan bahwa silase yang diinokulasikan menggunakan campuran beberapa bakteri asam laktat akan memiliki karakteristik kandungan BK yang lebih tinggi dibandingkan silase tanpa inokulasi. Hasil ini berbeda dengan yang dilaporkan oleh Contreras-Govea et al. (2013) bahwa penggunaan $L$. plantarum tidak memiliki pengaruh terhadap kandungan BK silase alfalfa jika dibandingkan dengan silase kontrol.

Kandungan BO silase KBK dengan penambahan dan tanpa inokulan menunjukkan perbedaan yang nyata $(P<0,05)$. Inokulasi $L$. plantarum berbeda tidak nyata terhadap silase kontrol (K0), sedangkan dengan penambahan inokulan $S$. cerevisiae terlihat berbeda nyata dibandingkan kontrol (K0). Inokulasi campuran L. plantarum dan S. cerevisiae memiliki kandungan $\mathrm{BO}$ tertinggi dibandingkan perlakuan yang lain. Hal ini menunjukkan bahwa penggunaan inokulan $S$. cerevisiae memiliki pengaruh terhadap kandungan $\mathrm{BO}$ silase $\mathrm{KBK}$ dibandingkan inokulan L. plantarum. Lateef et al. (2008) menyatakan bahwa KBK yang difermentasi dengan Rhizopuz stolonifer LAU 07 dengan penambahan $20 \%$ sukrosa selama 2 hari memiliki kandungan BO sebesar $79,2 \%$. KBK terinfeksi Phytopthora palmovera, dan Hellopeltis sp yang difermentasi dengan Aspergillus niger selama 6 hari memiliki kandungan BO masing-masing $90,06 \%$ dan 90,17\% (Mastika et al., 2011).

Kandungan SK silase KBK dengan penambahan dan tanpa inokulan menunjukkan perbedaan yang tidak nyata. Inokulasi L. plantarum, S. cerevisiae dan campurannya tidak mempengaruhi kandungan serat kasar silase KBK. Hal ini dipengaruhi bahwa kedua inokulan tersebut tidak memiliki kemampuan untuk menghasilkan enzim eksoglukanase, sehingga tidak memiliki pengaruh nyata terhadap kandungan SK silase KBK. Hasil ini berbeda dengan yang dilaporkan oleh Zakariah (2014) 
bahwa inokulasi campuran L. plantarum dan $S$. cerevisiae mengandung NDF dan ADF yang rendah (masing-masing $36,48 \%$ vs $46,37 \%$ dan $23,48 \%$ vs $30,07 \%$ ) dibanding silase tanpa inokulasi.

Kandungan PK silase KBK dengan penambahan dan tanpa inokulan menunjukkan perbedaan tidak nyata. Penggunaan inokulan tidak memiliki pengaruh terhadap kandungan PK jika dibandingkan dengan silase tanpa inokulan. Kandungan PK selalu tetap karena tidak adanya protein yang masuk dan keluar dari silo. Peningkatan kadar PK silase biasa terjadi karena adanya penurunan kandungan kimia seperti fraksi kandungan ekstrak eter atau yang lainnya, hal ini menjadikan persentase kadar PK meningkat. KBK fermentasi Phanerochaeta chyrosporium yang disuplementasi 3.300 ppm $\mathrm{CaCl}_{2}$ dan 320 ppm $\mathrm{MnSO}_{4} \mathrm{H}_{2} \mathrm{O}$ dengan lama fermentasi 25 hari memiliki kandungan PK sebesar 10,35\% (Nelson dan Suparjo, 2011).

Kandungan EE silase KBK dengan penambahan dan tanpa inokulan menunjukkan perbedaan yang nyata $(P<0,05)$. Penggunaan L. plantarum (KLp) menunjukkan perbedaan yang tidak nyata terhadap kandungan EE dibandingkan dengan silase kontrol (KO). Hal ini berbeda dengan yang dilaporkan oleh Van Ranst et al. (2009) bahwa proses Lipolisis yang terjadi pada silase Trifolium pretens (red clover) dengan penggunaan L. plantarum yaitu sekitar $60 \%$ lebih tinggi dibandingkan dengan silase dengan penambahan asam format yaitu sekitar $48 \%$.

Silase KBK dengan penggunaan $S$. cerevisiae (KSc) memiliki kandungan EE yang rendah dibandingkan dengan silase kontrol (K0). Potensi untuk menghasilkan enzim lipase oleh $S$. cerevisiae cukup tinggi, sehingga menjadikan kandungan EE silase menjadi rendah. Semakin lama fermentasi (inkubasi) dapat meningkatkan aktivitas enzim lipase yang dihasilkan khamir untuk merombak kandungan lemak substrat, karena khamir akan menyerang lemak dan protein setalah karbohidrat sebagai sumber energinya (Anggraeny dan Umiyasih, 2009).

Kandungan BETN silase dengan penambahan dan tanpa inokulan menunjukkan perbedaan yang nyata $(P<0,05)$. Silase KBK tanpa inokulan memiliki kandungan BETN yang cukup rendah, berbeda tidak nyata terhadap silase KBK dengan inokulasi $L$. plantarum. Inokulasi campuran $L$. plantarum dan S. cerevisiae (K0) memiliki nilai kandungan BETN yang lebih tinggi dibandingkan silase kontrol (K0). Fermentasi inokulan campuran $L$. plantarum dan $S$. cerevisiae cukup efektif sehingga memiliki kandungan BETN yang tertinggi.

Penambahan tepung gaplek sebanyak $20 \%$ pada semua perlakuan dapat mempengaruhi kandungan BETN silase KBK. Silase KBK tanpa penambahan aditif memiliki kandungan BETN sebesar 53,68\% (Olubajo et al., 1987). Penambahan gula terlarut seperti molases pada pembuatan silase yang

Tabel 4. Kualitas kimia silase kulit buah kakao ditambah gaplek sebagai kontrol $(\mathrm{K})$, kontrol + L. Plantarum $(\mathrm{KLp})$, kontrol + S. cerevisiae $(\mathrm{KSc})$, kontrol + L. plantarum + S. Cerevisiae $(\mathrm{KLp}+\mathrm{Sc})$ (change chemical composition on cocoa pod silage + cassava meal without inoculant as control $(K O)$, control + L. plantarum $(K L p)$, control + S. cerevisiae $(K S c)$, control $+L$. plantarum $+S$. cerevisiae $(K L p+S c))$

\begin{tabular}{|c|c|c|c|c|}
\hline \multirow{2}{*}{ Parameter } & \multicolumn{4}{|c|}{ Silase (silage) } \\
\hline & KO & KLp & KSc & $\mathrm{KLp}+\mathrm{Sc}$ \\
\hline Asam laktat (\% BK) (Lactic acid content $(\% D M))^{\mathrm{ns}}$ & $1,17 \pm 0,15$ & $1,52 \pm 0,28$ & $1,36 \pm 0,48$ & $1,04 \pm 0,18$ \\
\hline \multicolumn{5}{|l|}{ Kandungan (\%BK) (content $(\% D M))$} \\
\hline $\mathrm{BK}(D M)$ & $20,38 \pm 0,34^{a}$ & $22,20 \pm 1,31^{\mathrm{bc}}$ & $21,12 \pm 0,04^{a b}$ & $22,66 \pm 0,48^{c}$ \\
\hline $\mathrm{BO}(\mathrm{OM})$ & $93,72 \pm 0,24^{a}$ & $93,82 \pm 0,10^{\mathrm{ab}}$ & $94,27 \pm 0,31^{b c}$ & $94,43 \pm 0,26^{c}$ \\
\hline $\mathrm{SK}(C F)^{\mathrm{ns}}$ & $18,92 \pm 0,78$ & $18,16 \pm 0,37$ & $17,51 \pm 1,76$ & $15,83 \pm 1,65$ \\
\hline $\mathrm{PK}(C P)^{\mathrm{ns}}$ & $3,41 \pm 0,09$ & $3,50 \pm 0,44$ & $3,21 \pm 0,19$ & $2,99 \pm 0,14$ \\
\hline EE & $0,87 \pm 0,15^{\mathrm{c}}$ & $0,71 \pm 0,35^{\mathrm{bc}}$ & $0,33 \pm 0,23^{a b}$ & $0,15 \pm 0,09^{a}$ \\
\hline $\operatorname{BETN}(N F E)$ & $70,51 \pm 1,03^{a}$ & $71,45 \pm 0,38^{a}$ & $73,22 \pm 2,06^{a b}$ & $75,46 \pm 1,68^{b}$ \\
\hline
\end{tabular}

BK: bahan kering (dry matter), BO: bahan organik (organic matter), SK: serat kasar (crude fiber), PK: protein kasar (crude protein), EE: ekstrak eter (extract ether), BETN: bahan ekstrak tanpa nitrogen (nitrogen free extract).

a,b,c Superskrip yang berbeda pada baris yang sama menunjukkan perbedaan nyata $(P<0,05)($ different supercripts at the same row indicate significant differences $(P<0.05))$.

ns tidak berbeda nyata (non significant). 
kurang mengandung gula terlarut sangat berpengaruh pada penurunan kandungan BETN dalam silase (Isnandar, 2011).

\section{Kesimpulan}

Hasil penelitian menunjukkan bahwa inokulan campuran $L$. plantarum dengan $S$. cerevisiae meningkatkan kualitas organoleptik (meliputi warna dan keberadaan jamur), serta kandungan BK, BO, BETN yang tinggi dibandingkan silase tanpa inokulasi. Inokulan campuran L. plantarum dengan S. cerevisiae efektif untuk mempertahankan kualitas silase.

\section{Daftar Pustaka}

Adesoji, A. T., A. A. Ogunjobi, O. Ezekiel Fagade and O. Jacob Babayemi. 2010. Effect of Lactobacillus plantarum Starter Culture on the Microbial Succession, Chemical Composition, Aerobic Stability and Acceptability by Ruminant of Fermented Panicum maximum Grass. AU J. T 14: 1-24.

Anggraeny, Y. N. and U. Umiyasih. 2009. Pengaruh fermentasi Saccharomyces cerevisiae terhadap kandungan nutrisi dan kecernaan ampas pati aren (Arenga pinnata). Prosiding Seminar Nasional Teknologi Peternakan dan Veteriner.

Aquilina, G., G. A. Chesson, P. S. Cocconcelli, J. D. Knecht, N. A. Dierick, M. A. Gralak, J. Gropp, I. Halle, C. Hogstrand, R. Kroker, L. Leng, S. L. Puente, A. L Haldorsen, A. Mantovani, G. Martelli, M. Mezes, D. Renshaw, M. Saarela, K. Sejrsen, and J. Westendorf. 2012. Scientific Opinion on the safety and efficacy of Lactobacillus plantarum (NCIMB 41028) and Lactobacillus plantarum (NCIMB 30148) as silage additives for all animal species EFSA Journal 10: 1-11.

Astuti, M. 1980. Rancangan Percobaan. Fakultas Peternakan, Universitas Gadjah Mada, Yogyakarta.

Baker, S. B. and W. H. Summerson. 1941. The colorimetric determination of lactic acid in biological material J. Biol. Chem. 138: 546-554.

Barnes, R. F., C. J. Nelson, K. J. Moore and M. Collins. 2007. Forages The Science of Grassland Agriculture. Blackwell Publishing, lowa.
Cai, S. and X. Dong. 2010. Cellulosilyticum ruminicola gen. nov., sp. nov., isolated from the rumen of yak, and reclassification of Clostridium lentocellum as Cellulosilyticum lentocellum comb. nov. Int. J. Sys. Evol. Microbiol. 60: 845-849.

Cherney, D. J. R., J. H. Cherney and L. E. Chase. 2004. Lactation performance Fries Holstein cows fed fescue, orchardgrass, or alfalfa silage. J. Dairy Sci. 87: 2268-2276.

Contreras-Govea, F. E., R. E. Muck, G. A. Broderick and P. J. Weimer. 2013. Lactobacillus plantarum effect on silage fermentation and in vitro microbial yield. Anim. Feed Sci. 179: 61-68.

Dalié, D. K. D., A. M. Deschamps and F. Richard-Forget. 2010. Lactic acid bacteria-Potential for control of mould growth and mycotoxins: A review. Food Control 21: 370-380.

Despal, I. G. Permana, S. N. Safarina, dan A. J. Tatra. 2011. Penggunaan berbagai sumber karbohidrat terlarut air untuk meningkatkan kualitas silase daun rami. Media Peternakan 34: 69-76.

Heinritz, S. N., S. D. Martens, P. Avila and S. Hoedtke. 2012. The effect of inoculant and sucrose addition on the silage quality of tropical forage legumes with varying ensilability. Anim. Feed Sci. Tech. 174: 201-210.

Hippen, A. R., D. J. Schingoethe, K. F. Kalscheur, P. L. Linke, D. R. Rennich, M. M. Abdelqader and I. Yoon. 2010. Saccharomyces cerevisiae fermentation product in dairy cow diets containing dried distillers grains plus solubles. J. Dairy Sci. 93: 2661-2669.

Isnandar. 2011. Silase isi rumen sebagai pakan pengganti hijauan jagung terhadap produksi susu sapi perah peranakan Frisien Holstein. Disertasi Fakultas Peternakan, Universitas Gadjah Mada, Yogyakarta.

Jatkauskas, J. and V. Vrotniakiene. 2007. Effect of Lactobacillus plantarum, Pediococcus acidilactici, Enterecoccus faecium and Lactobacillus lactis microbial supplementation of grass silage on the fermentation characteristic in rumen dairy cows. Vet. Zootech 40: 29-34. 
Johnson, H. E., R. J. Merry, D. R. Davies, D. B. Kell, M. K. Theodorou and G. W. Griffith. 2005. Vacuum packing: a model system for laboratory-scale silage fermentations. J. Appl. Microbiol. 981: 106-113.

Kamal, M. 1997. Kontrol Kualitas Pakan Ternak. Laboratorium Makanan Ternak. Jurusan Nutrisi Makanan Ternak, Fakultas Peternakan, Universitas Gadjah Mada, Yogyakarta.

Kurnianingtyas, I. B., P. R. Pandasari, I. Astuti, S. D. Widyawati, dan W. P. S. Suprayogi. 2012. Pengaruh macam akselerator terhadap kualitas fisik, kimiawi, dan biologi silase rumput kolonjono. Trop. Anim. Husb. 1: 7-14.

Lateef, A., J. Oloke, E. B. G. Kana, S. O. Oyeniyi, O. R. Onifade, A. O. Oyeleye, O. C. Oladosu and A. O. Oyelami. 2008. Improving the quality of agrowastes by solid-state fermentation: enhanced antioxidant activities and nutritional qualities. World J. Microbiol. Biotechnol. 24: 2369-2374.

Li, Y. and N. Nishino. 2011. Monitoring the bacterial community of maize silage stored in a bunker silo inoculated with Enterococcus faecium, Lactobacillus plantarum and Lactobacillus buchneri. J. Appl. Microbiol. 110: 1561-1570.

Mastika, I. M., I. W. Supartha, A. W. Puger and I. K. M. Budiasa. 2011. Aspergilus niger significantly improved nutrient content and quality of cocoa waste (Theobroma cacao L.). The Excellence Research Universitas Udayana 34-38.

McDonald, P., R. A. Edwards and J. F. D. Greenhalgh. 2002. Animal Nutrition. Prentice Hall, London.

Nahm, K. H. 1992. Practical Guide to Feed, Forage and Water Analysis. Yoo Han Publisher, Seoul.

Nelson dan Suparjo. 2011. Penentuan lama fermentasi kulit buah kakao dengan Phanerochaeta crysosporium: evaluasi kualitas nutrisi secara kimiawi. Agrinak 1: 1-10.
Olubajo, F. O., M. M. Asonibare and E. O. Awolumate. 1987. Cocoa pod silage and cocoa pod grass silage in goat and sheep nutrition. Overcoming constraints to the efficient utilization of agricultural by-product as animal feed. Said A. N., B. H. Dzowela, A. A. Adegbola, J. A. Kategile, D. A. Little, M. A. Naga and S. Sibanda (eds). Proceeding of the Fourth Annual Workshop held at the Institute of Animal Research, Mankon station, Bamenda, Cameroon.

Ranjit, N. K. and L. Kung. 2000. The effect of Lactobacillus buchneri, Lactobacillus plantarum, or a chemical preservative on the fermentation and aerobic stability of corn silage. J. Dairy Sci. 83: 526-535.

Ridla, M., N. Ramli, L. Abdullah and T. Toharmat. 2007. Milk yield quality and safety of dairy cattle fed silage composed of organic components of garbage. J. Ferment. Bioeng. 77: 572-574.

Sianipar, J. and K. Simanihuruk. 2009. Performans kambing sedang tumbuh yang mendapat pakan tambahan mengandung silase kulit buah kakao. Prosiding Seminar Nasional Teknologi Peternakan dan Veteriner.

Sofyan, A., L. M. Yusiati, Y. Widyastuti and R. Utomo. 2011. Microbiological characteristic and fermentability of king grass (Pennisetum hybrid) silage treated by lactic acid bacteria-yeast inoculant consortium combined with rice bran addtion. Journal of the Indonesian Tropical Animal Agriculture 36: 265-272.

Soleh, A. Z. 2005. Ilmu Statistika Pendekatan Teoritis dan Aplikatif disertai Contoh Penggunaan SPSS. Penerbit Rakayasa Sains, Bandung.

Van Ranst, G., V. Fievez, J. De Reik and E. Van Bockstaele. 2009. Influence of ensiling forages at different dry matters and silage additives on lipid metabolism and fatty acid composition. Anim. Feed Sci. Tech. 150: 62-74.

Zakariah, M. A. 2014. Pengaruh penggunaan inokulum campuran Lactobacillus plantarum dan Saccharomyces cereviriae pada silase kulit buah terhadap komposisi kimia dan kecernaan in vitro. Skripsi Fakultas Peternakan, Universitas Gadjah Mada, Yogyakarta. 